\title{
PRACTICAL ISSUES IN DEVELOPING A SMART SURFACE IRRIGATION SYSTEM WITH REAL-TIME SIMULATION OF FURROW ADVANCE ${ }^{\dagger}$
}

\author{
S. SHAHIDIAN*, R. P. SERRALHEIRO AND J. M. SERRANO \\ Instituto de Ciências Agrárias e Ambientais Mediterrânicas, Universidade de Évora, Núcleo da Mitra, Ap. 94, 7002-554, Évora, Portugal
}

\begin{abstract}
Automation of surface irrigation can be an economic and ecological way of increasing global food production. In this work a fully automated cablegation system is evaluated that adapts the application time and depth to the actual infiltration rate of the soil in real-time. The system calculates the infiltration equation from advance times in a control furrow and then simulates irrigation in every furrow of the field, establishing the optimum application time for each furrow. The methodology was evaluated in a field organized in contour terraces with furrows of various lengths in order to evaluate practical issues affecting the performance of the system. The results confirm the temporal variability in soil infiltration, and the need for real-time determination of the infiltration equation. The evolution of furrow geometry through the season did not have an important impact on the results of the simulations. The length of the furrow considered for calculating the Kostiakov equation influences the parameters of the equation. Automation with real-time feedback can result in important savings in water and labour and can produce irrigation events with more than $90 \%$ application efficiency. Nevertheless, the results also indicate that there are practical limits to what can possibly be achieved with automation and real-time feedback from the field. Copyright (C) 2013 John Wiley \& Sons, Ltd.
\end{abstract}

KEY WORDS: surface irrigation; cablegation; automation; PLCs; Kostiakov; infiltration; terrace

Received 3 November 2010; Revised 25 September 2012; Accepted 26 September 2012

\section{RÉSUMÉ}

L'automatisation de l'irrigation de surface peut être un moyen économique et écologique pour augmenter la production alimentaire mondiale. Le système évalué ici est un siphon californien de surface dont l'automatisme adapte le temps d'application et la dose à la vitesse d'infiltration réelle dans le sol mesurée en temps réel. Le système calcule l'équation de l'infiltration à partir de l'avancement dans une raie de contrôle et simule ensuite l'irrigation pour toutes les autres raies du champ, établissant le temps d'application optimal pour chacune. La méthodologie a été évaluée sur un champ organisé en terrasses successives avec des billons de longueurs différentes afin d'évaluer les problèmes pratiques qui affecteraient la performance du système. Les résultats confirment la variabilité temporelle de l'infiltration des sols, et la nécessité d'une détermination en temps réel de l'équation d'infiltration. L'évolution de la géométrie de la raie pendant la saison n'a pas eu d'incidence importante sur les résultats des simulations. La longueur de la raie considérée pour le calcul de l'équation Kostiakov influence les paramètres de l'équation. L'automatisation avec rétroaction en temps réel peut entraîner des économies importantes d'eau et de main d'œuvre et peut produire des événements d'irrigation avec une efficacité d'application de plus de $90 \%$. Néanmoins, les résultats indiquent également qu'il existe des limites pratiques à ce qui peut éventuellement être atteint grâce à l'automatisation et la rétroaction en temps réel sur le terrain. Copyright @ 2013 John Wiley \& Sons, Ltd.

MOTS CLÉS: irrigation de surface; siphon californien; automatisation; Kostiakov; infiltration; terrasses

\footnotetext{
* Correspondence to: S. Shahidian, Universidade de Évora, ICAAM. Apartado 94, 7000 Évora, Portugal. E-mail: shakib@uevora.pt

${ }^{\dagger}$ Les questions pratiques du développement d'un système intelligent d'irrigation de surface avec simulation en temps réel de l'avancement de l'écoulement dans la raie.
} 


\section{INTRODUCTION AND OBJECTIVES}

Soil infiltration characteristics are usually expressed in a time-dependent infiltration equation, the most common type being the Kostiakov equation (Kostiakov 1932):

$$
Z=k t^{a}
$$

where $Z$ is the cumulative infiltration depth $(\mathrm{mm}), t$ is infiltration opportunity time $(\mathrm{min}), k$ is a coefficient indicating initial infiltration $\left(1 \mathrm{~min}^{-\mathrm{a}} \mathrm{m}^{-1}\right)$ and $a$ is an exponent indicating the shape of the accumulated infiltration curve. The Kostiakov-Lewis equation adds a parameter, $f_{0}$, to account for the basic infiltration rate in more permeable soils where infiltration does not tend to zero over time. Alvarez (2003) assumed that $k$ was proportional to the inflow rate, and that the value of $a$ did not vary with inflow rate.

Advance data can be used to calculate the coefficients of the Kostiakov equation, and result in excellent infiltration equations for simulating the advance phase, while equations obtained from inflow-outflow data are better at predicting the runoff volumes and cumulative infiltration (Khatri and Smith, 2005). The two-point method of Elliot and Walker (1982) is a practical method using advance data, and resorts to the volume balance equation which specifies that cumulative infiltrated volume $\left(k t^{a} x\right)$ is equal to total applied water $\left(Q_{0} t\right)$ minus surface storage $\left(A_{0} x\right)$ :

$$
k t^{a} \sigma_{z} x=Q_{0} t-A_{0} \sigma_{y} x
$$

where $\sigma_{z}$ is the subsurface shape factor, $Q_{0}$ inflow rate, $t$ application time, $x$ distance the front has advanced in time $t$, and $\sigma_{y}$ is a surface storage shape factor usually assumed to be 0.77 (Walker and Skogerboe, 1987).

The subsurface shape factor is calculated from the Kiefer correction factor:

$$
\sigma_{z}=\frac{a+r(1-a)+1}{(1+a)(1+r)}
$$

where $r$ is the exponent of the advance curve approximated by an exponential function, obtained from measuring advance time in two points:

$$
x=p t^{r}
$$

The method poses two volume balance equations, based on the advance time to the mid-distance, $t_{\mathrm{m}}$, and at the downstream end of the field, $t_{1}$, and then, the parameters of the Kostiakov equation $k$ and $a$, are calculated through a logarithmic transformation:

$$
a=\frac{\ln \left(V_{l} / V_{m}\right)}{\ln \left(t_{l} / t_{m}\right)}
$$

and

$$
k=\frac{V_{l}}{\sigma_{z} t_{l}^{a}}
$$

where $V_{\mathrm{m}}$ and $V_{1}$ are the volumes infiltrated during advance to the middle and end of the furrow, and $t_{\mathrm{m}}$ and $t_{1}$ are the advance times to the middle and end of the furrow. Advances in modelling infiltration and advance in surface irrigation (Souza, 1981; Strelkoff and Clemmens, 1981; Elliot and Walker, 1982) have opened new horizons for designing efficient irrigation systems.

Resistance to flow is a function of particle size and furrow shape and can be defined by Manning's $n$, which is a dimensionless number. Additionally Manning's $n$ incorporates other factors such as irregularity of the furrow cross section, vegetation, sedimentation, and obstructions in the furrow, especially during the first irrigation (Barfield et al., 1981; Ettedali et al., 2012). Although roughness can be considered to be an intrinsic property of the soil surface, studies show (Sepaskhah and Bondar, 2002) that the roughness coefficient varies inversely with inflow rates and directly with slope of furrows.

The temporal and spatial variability of infiltration is simultaneously the major challenge to automation of surface irrigation and the most important determinant of irrigation system performance (Oyonarte et al., 2002). Because of this variability, any automation systems needs to establish infiltration parameters in real-time, and thus needs to incorporate some sort of feedback from the field.

Humphries and Trout (1990) developed a computerized system controlled by the feedback of information on the volume of tail water leaving the field. Walker and Busman (1990), Azevedo et al. (1996) and Khatri and Smith (2007) developed irrigation control systems based on real-time determination of the infiltration equation and appropriate modification of the management variables. However, these methodologies are not fully automated and require farmer intervention.

Lam et al. (2007) used a ground-based remote-sensing feedback control system to monitor the advance of water down a furrow, and allow automatic control of water discharge at the furrow inlet during furrow irrigation. A camera, located at the field boundary, captured images of water flowing down a furrow during an irrigation event. The images were analysed by a machine vision system to calculate the actual position of the leading edge of the water. Niblack and Sanchez (2008) developed an automated surface irrigation system that is controlled by either cut-off time or cut-off distance. The cut-off time control uses a standard commercial 
sprinkler controller to operate the gates. The cut-off distance system uses commercial radio transmitters and transceiver-relays commonly used to operate security systems. In Australia Irrimate produces advance sensors that are placed at various points along the length of the field and are triggered by the advancing water front. The advance times are downloaded to a hand-held computer after the irrigation event and used in the evaluation of furrow irrigation.

Khatri and Smith (2006) reviewed some of the methods for real-time management of irrigation and found that they were too data-intensive for easy field application. These authors proposed the real-time prediction of the infiltration parameters from a single observation of the irrigation advance during the irrigation event being controlled. Gillies et al. (2010) additionally proposed simulation of the irrigation and optimization to determine the preferred time to cut off the inflow to the field using what they called a SISCO simulation engine.

Cablegation was developed in the early 1980s by the USDA- ARS at Kimberly, Idaho, as a means of providing farmers with an alternative to higher-energy-consuming sprinkler systems (Trout et al., 1990; Walker, 1989). Cablegation uses gated pipe to sequentially irrigate long furrows (Kemper, 1981; Kemper et al., 1987) with a characteristic progressive cutback inflow. The 'gates' or outlets are near the top side and are left open. The pipe is laid on a precise grade and a plug moves slowly through the pipe causing water to flow, sequentially, into the furrows. A cable or line from a reel at the pipe inlet is attached to the plug and is reeled out according to the desired rate at which the irrigation is to progress across the field. Water flows in the pipe below the level of the outlets until it reaches the plug (Figure 1). This obstruction causes the water to fill the pipe and run out of the outlets near the plug. Flow in any furrow gradually decreases as the plug moves downstream. This creates a typical hydrograph with a gradual cut-back that should be designed to match the natural decrease in soil infiltration rate and help reduce tailwater runoff. Because the system encourages rapid initial advance and later cutback of flow, water application is more uniform, and runoff and deep percolation are reduced (Jayasudha and Chandrasekaran, 2001; Moravejalahkami et al., 2009).

Although initially successful, the actual number of cablegation systems in use today is limited. Some of the main constraints that led to the abandonment of many cablegation systems were the need for a rectangular field, component failure, difficulty in using the mechanical controller, infiltration variability, and installation constraints (Trout et al., 1990). The development of a smart and reliable cablegation controller using today's freely available electronics should obviate some of these issues. An electronically controlled cablegation with feedback from the field can effectively overcome the limitations with a rectangular field, the difficulty in using the mechanical controller, and reduce component failure and problems rising from infiltration variability.
The main challenge to the automation of surface irrigation is that performance is highly influenced by the infiltration characteristics of the soil, which change with initial soil water content, roughness and from one irrigation event to the next. Thus, an automatic surface irrigation system must be capable of measuring infiltration or advance during the early stages of the irrigation and make the necessary adjustments to application rate and depth. Since cablegation progressively irrigates a limited number of furrows, it is ideal for the implementation of feedback systems. The actual field geometry and its organization, such as terracing, often result in furrows of different length, needing adaptation of the volumes applied.

Thus, the main objective of this work is to assess practical issues and the validity of certain premises accepted and used in the design of automated surface irrigation with feedback from the field:

- precision of the simulations of hydrogram from the gated pipe;

- validity of using an infiltration equation obtained for a furrow of a given length to simulate advance in furrows of different lengths;

- influence of the natural field variability on the infiltration properties and system performance;

- validity of using a given furrow geometry during the whole irrigation season;

- influence of the natural decrease in soil infiltration on the system performance;

- performance of a simple simulation model running on a microcontroller, compared to much more elaborate simulation models running on PCs.

In the present work a feedback system with real-time simulation of furrow advance is used to adapt the application times to existing soil infiltration and individual furrow lengths. The system uses advance times to calculate the Kostiakov infiltration equation and then simulates advance in the remaining furrows of the field. The methodology uses Manning's roughness coefficient to calibrate the advance simulations and thus improve their precision. The proposed system was subject to real field conditions in order to evaluate the above-mentioned issues and their possible influence on the performance of automated surface irrigation, particularly on the proposed automation system.

\section{MATERIALS AND METHODOLOGIES}

\section{Software}

Specifically developed software was used to fully manage the irrigation event without human intervention, with the necessary routines to collect advance data, simulate 
irrigation and then manage the irrigation event in real-time. The program loads field and furrow geometry as well as system configuration data such as individual furrow lengths and slopes, total available flow rate, gate spacing and opening. It then calculates the flow hydrogram based on total inflow into the pipe and the gate opening. Once irrigation starts, the controller parks the plug at the first set of furrows and makes a measurement of the advance to the middle and end of a pre-defined control furrow. Two wireless water sensors inserted at halfway and at the end of the control furrow provide the controller with the advance times needed to calculate the infiltration equation.

From these measurements and the furrow geometry, the infiltration module calculates in real-time the parameters of the Kostiakov infiltration equation without the steady-state term through the two-point method of Elliot and Walker (1982). Manning's roughness coefficient is determined as a 'calibrating' parameter by the flow simulation model to adjust simulated advance times to those observed in the control furrow. The simulation engine then simulates advance in each individual furrow and adjusts individual application times. It then calculates and stores the time when irrigation should begin in each successive furrow. Once the simulations are over, then the program starts irrigating the furrows according to the individual advance times and the set application depth. At the end of the irrigation it parks the plug and disconnects the water supply.

Inflow hydrogram. In cablegation the total inflow is distributed to a series of gates in a characteristic progressively decreasing hydrogram. Calculation of the exact hydrogram is important for the correct simulation of advance in the furrows. This calculation is performed in a recursive process starting from the first gate located upstream of the flow and was described originally by Kemper and Kincaid (1982). The flow from each orifice $Q_{i}$, in $1 \mathrm{~min}^{-1}$, is calculated using a modified Bernoulli equation:

$$
Q_{i}=0.0066 C_{\mathrm{d}} D^{2} \sqrt{h}_{i}
$$

where $h_{i}$ is the pressure head at the orifice, $\mathrm{mm}, C_{\mathrm{d}}$ is the discharge coefficient, usually 0.65 , and $D$ is the equivalent diameter of the orifice, $\mathrm{mm}$ (equivalent diameter is the diameter of a circle with the same area as the gate opening).

For the first gate, the head can be assumed to be half the vertical distance between two consecutive gates. For each consecutive gate, it is given by

$$
h_{i+1}=h_{i}+S d-h_{\mathrm{f}}+\left(v_{i}^{2}-v_{i+1}^{2}\right) / 2 g
$$

where

$$
\begin{aligned}
h_{i+1} & =\text { pressure head at orifice } i \text { and } i+1, \mathrm{~mm} \\
d & =\text { distance between gates, } \mathrm{mm}
\end{aligned}
$$

$$
\begin{aligned}
& h_{\mathrm{f}} \quad=\text { head loss due to friction, } \mathrm{mm} \\
& v_{i}, v_{i+1}=\text { speed of flow in the pipe upstream from orifice } \\
& i \text {, and } i+1, \mathrm{~m} \mathrm{~s}^{-1} \\
& S \quad=\text { pipe slope in } \mathrm{m} \mathrm{m}^{-1}
\end{aligned}
$$

The friction loss, $h_{\mathrm{f}}$, is given by the Hazen Williams equation:

$$
h_{f}=6.20 \times 10^{6} \frac{d}{D^{4.856}}\left(\frac{Q_{\mathrm{t}}}{C}\right)^{1.85}
$$

where $Q_{\mathrm{t}}$ is the total flow in $1 \mathrm{~min}^{-1}$. The speed of flow can be calculated as $v_{i}=229 Q^{2} / D$. The recursive process is finished when cumulative water leaving the gates totals the inflow into the pipe.

Simulation. A Eulerian space-time grid is used to simulate advance in the furrows using a fixed time-step of $1 \mathrm{~min}$ for calculating advance and infiltration in each cell of the grid. It starts from a known upstream condition and proceeds in the forward direction, calculating for each time-step the flow area and discharge at each cell, as well as accumulated infiltration in these cells. The difference between inflow and total infiltration and surface storage in every cell provides the volume available for advance in the next time-step.

The advance distance in each time-step is calculated from velocity, which in turn is calculated using the Manning uniform flow equation, and then stored in the program as the length of the new cell. Advance rate, $V_{\mathrm{el}}\left(\mathrm{m} \mathrm{min}^{-1}\right)$ can be established based on flow rate, $Q$, furrow geometry and slope using the following expression originally presented by Trout (1992) derived from Manning's uniform flow equation:

$$
V_{e l}=a_{v} Q\left(Q \frac{n}{\sqrt{S}}\right)^{-3 u /(5 u-2)}
$$

where

$$
a_{v}=a_{w p}^{2 /(5 u-2)}
$$

and $a_{w p}$ and $u$ are empirical coefficients obtained from average furrow geometry:

$$
A=a_{w p} w p^{u}
$$

The volume infiltrated in each time increment, $V_{\text {infl }}$, along the furrow, is calculated as

$$
V_{\text {infl }}=\int_{0}^{m}\left(E(s) k^{\prime} \tau^{a^{\prime}}\right) d_{s}
$$

where $E(s)$ is the length of the cell $s,(\mathrm{~m}), k^{\prime}$ and $a^{\prime}$ are the parameters of time derivate of the infiltration equation and 
$\tau$ is the infiltration opportunity time. The cross-section area of surface storage is a function of the flow rate in the cell and can be obtained through Manning's equation:

$$
A=a_{a}\left(Q \frac{n}{\sqrt{S}}\right)^{3 u /(5 u-2)}
$$

where

$$
a_{a}=a_{w p}-2 /(5 u-2)
$$

In each new time-step, the flow rate available for the advance front in the new tip cell is established through a volume balance of the inflow, infiltrated and stored volumes from the start of irrigation in the furrow:

$$
Q_{(s+1)}=\left(V_{t t l}-V_{i n f t l l}-V_{s u r t t l}\right) / t_{i n c}
$$

where

$$
\begin{array}{ll}
Q_{(s+1)} & =\text { flow rate available for cell } s+1 \\
V_{\mathrm{ttl}} & =\text { total volume applied to the furrow } \\
t_{\text {inc }} & =\text { total time since the beginning of irrigation } \\
& \text { in the furrow } \\
V_{\text {surttl }} & =\text { total surface storage } \\
V_{\text {inftll }} & =\text { total volume infiltrated in the furrow }
\end{array}
$$

An advantage of the proposed simulation model is that it does not need any input parameters besides those already used for determining the infiltration equation.

For each irrigation, Manning's roughness coefficient is calculated as a fitting parameter between the simulated and observed advance times in the control furrow. This calibration is achieved through iteration. An initial value of 0.04 is arbitrated for $n$, and a first simulation is carried out with this value. If the advance time is overestimated by the simulation model, then $n$ is increased by 0.0025 , and vice versa. The iteration continues until changes to the value of $n$ do not produce any improvements in the simulation of advance. In this way, each irrigation is performed with the actual infiltration equation of the soil as well as furrow surface roughness. Greater detail on the simulation model can be found in Shahidian and Serralheiro (2012).

\section{Equipment}

The irrigation controller evolved over time, as new technologies became available and the original cablegation design was modified. In the first year a SIEMENS Micromaster inverter along with a motor were used to control the speed of the plug moving in the gated pipe. The Micromaster uses three-phase current to control the speed of the motor with high precision. The irrigation control software was run on a PC, and the motor speeds were manually entered into the inverter.

An important observation from the field trials was that the plug does not need to move continuously down the pipe, at different speeds. Instead, the plug only needs to open the gates at the designated time. It was found that this could be achieved by a simple on-off movement. The plug can stay stationary and then move to the next gate when needed. Based on this observation, it was possible to build a modified PC to directly control the irrigation through the printer port (LPT1). The PC sends a $5 \mathrm{~V}$ signal to the printer port to print characters. This signal can be used to operate a $5 \mathrm{~V}$ relay and switch an electric motor. A $12 \mathrm{~V}$ electric motor with a 250:1 reduction head was used to control the movement of the plug (Figure 2).

The final version of the equipment was based on a Toshiba TMP95C061 microcontroller. It is a 16-bit microcontroller working at $25 \mathrm{MHz}$. A CipherLAB 520 PLC was selected, which is available with integrated flash memory for the program, a text display, a simple keyboard, $\mathrm{I} / \mathrm{O}$ ports for receiving furrow advance data and four relays to control pumps, valves and other equipment. The programming was done in BASIC and then compiled for the Toshiba microcontroller.

A $12 \mathrm{~V}, 25 \mathrm{~W}$ DC electric motor was used along with a 293 reduction gearbox to control the movement of the plug along the gated pipe. The whole system was powered by a $10 \mathrm{~W}$ solar panel mounted above the controller which charges a $12 \mathrm{~V} 7 \mathrm{~A}$ gel battery through a voltage regulator, thus providing for continuous operation during the night. Two $5 \mathrm{~V}$ relays allow the PLC's output port to operate the motor in both directions. The PLC and the other electronic parts were enclosed in a weatherproof box.

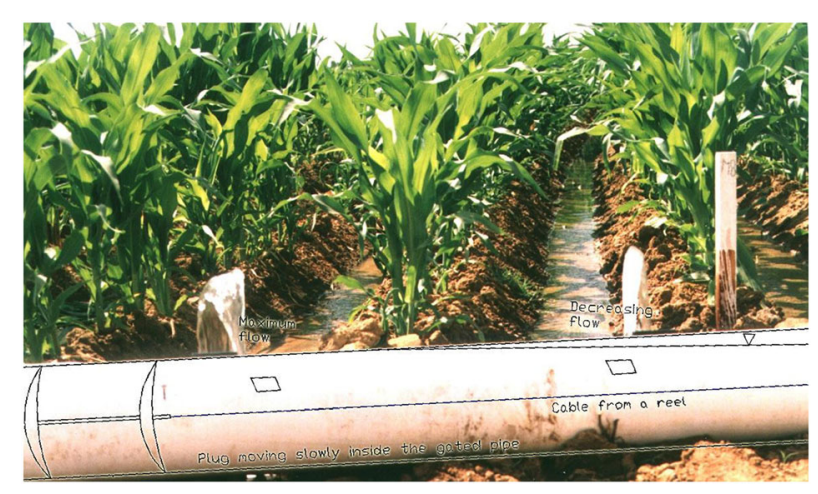

Figure 1. Detail of a cablegation system showing the plug moving slowly inside a gated pipe driven by the potential and kinetic energy of the water. As the plug moves away from a gate, the flow rate decreases progressively in that gate, so an ideal hydrogram is applied with a series of gradual cut-backs. A controller at the inlet establishes the timing for irrigation in each consecutive furrow. This figure is available in colour online at wileyonlinelibrary.com/journal/ird 


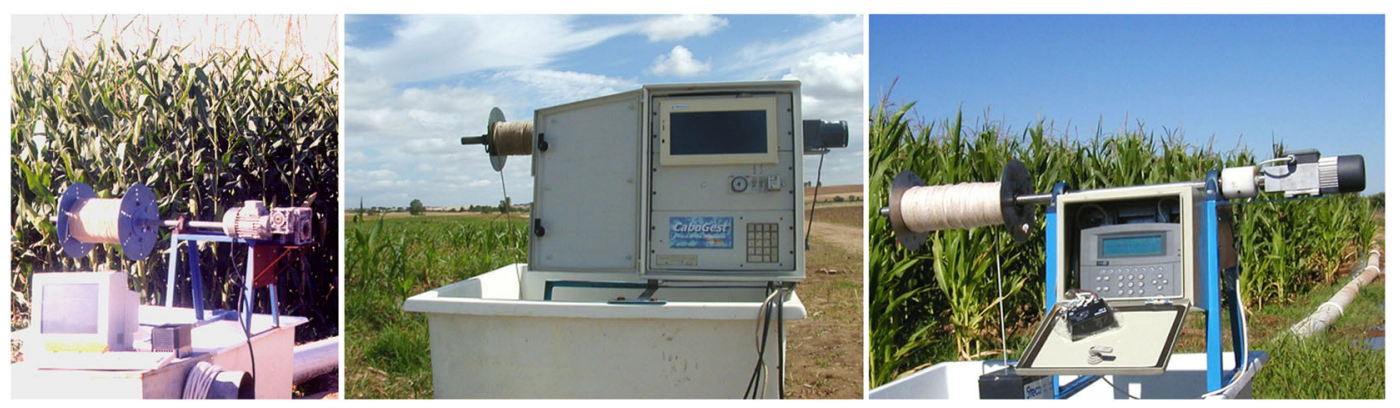

Figure 2. Evolution of the automatic controller. Left: the first version using an inverter to control the motor and the movement of the pulg. Centre: second version using a modified PC to directly control the motor. Right: final version using a microcontroller to fully operate the irrigation system. This figure is available in colour online at wileyonlinelibrary.com/journal/ird

\section{Site description and methods}

The field trials were carried out between 1998 and 2008 at three different research stations in southern Portugal, presenting soils that are typical of the region (Divor Station: Luvissol, Comenda Station: Calcic Luvissol and Outeiro Station: Vertic Luvissol). All irrigation data presented in this work are from years 1,2 and 3 at the Divor Station, where the weak structure of the soil with a B horizon of low permeability and the organization of the field in contour terraces provided the most challenging conditions for surface irrigation. A 3.5 ha field was organized in six contour terraces, each $30 \mathrm{~m}$ wide. This resulted in 179 free-drained furrows varying between 50 and $300 \mathrm{~m}$ in length, with a slope of $0.22 \%$. A gated pipe was laid on a precise grade of $2 \%$ slope to supply water to the furrows.

Advance times were measured at $20 \mathrm{~m}$ intervals along selected furrows. Furrow geometry was measured at 3 points along 12 selected furrows using a sliding bar profilometer and then averaged. Water was supplied by the Water Users' Association canal with long-crested weirs and orifice turnout combination providing a fairly constant turnout discharge of $101 \mathrm{~s}^{-1}$.

In year 1, the field had just been organized in contour terraces, and thus the furrows were opened on loose soil. In year 2, the surface of the soil was mobilized with a disk harrow before opening the furrows. In year 3 a minimum tillage system was implemented, under which herbicide was used to control weeds and the furrows were maintained from the previous year with no mobilization. Every year hybrid corn was planted directly on ridges using a direct sowing planter and a density of $1.1 \times 10^{5}$ plants per ha. Two irrigations were carried out to ensure crop emergence and then the furrows were reopened in order to obtain uniform, smooth furrows. The two irrigations before reopening the furrows were not considered in this work.

Application efficiency (AE) is very common in assessing the performance of surface irrigation. It is expressed as a percentage of the total applied water, $V_{\text {inflow }}$, that is contributing to the target, $V_{R Z}$ (Burt et al., 1997). In the Divor
Station all the water that did not leave the field as runoff was considered to be beneficial since there were no losses by percolation.

$$
\mathrm{AE}=100 \frac{V_{R z}}{V_{\text {inflow }}}
$$

\section{RESULTS AND DISCUSSION}

\section{Influence of furrow length and measuring points on the Kostiakov equation}

It is generally accepted that infiltration equations obtained using the two-point method should preferably be used for simulating advance under similar conditions to those in which they were established. Since organization of the Divor field in contour terraces resulted in furrows ranging from 50 to $300 \mathrm{~m}$ in length, it was important to study the effect of furrow length and the location of the measuring points on the resulting infiltration equations.

A study was carried out using an average synthetic advance curve obtained from four advances. Based on this advance curve and using average furrow geometries, 15 different combinations of distance to the first and second measuring points, $l_{\mathrm{m}}$ and $l_{1}$ respectively, were considered and the Kostiakov infiltration equation established for each combination (Table I).

Although these equations are from the same advance curve and the same soil geometry and flow rate, the exponent $a$ increases with the length of the furrow considered, $l_{1}$, and with distance to the first measuring point, $l_{\mathrm{m}}$. On the other hand, $k$ has an inverse behaviour, decreasing with an increase in $l_{\mathrm{m}}$ and $l_{\mathrm{l}}$. The combined effect is a progressive increase in infiltration with the increase in $l_{\mathrm{m}}$ and $l_{1}$ (Figure 3).

An explanation for this phenomenon might reside in the linear relation between the exponent $a$ of the equation and the average speed of advance to $l_{1}$ (Figure 4 , left). The longer the length of furrow considered, the slower will be the average speed, which the two-point method understands as greater infiltration per unit length of the furrow. Since $a$ is 
Table I. Combination of distance to the first and second measuring points, $\boldsymbol{l}_{\mathbf{m}}$ and $\boldsymbol{l}_{\mathbf{l}}$, and the resulting parameters of the Kostiakov equation

\begin{tabular}{|c|c|c|c|c|c|c|c|}
\hline$l_{\mathrm{m},(\mathrm{m})}$ & $l_{1,(\mathrm{~m})}$ & $t_{\mathrm{m},(\min )}$ & $t_{1,(\min )}$ & $\boldsymbol{k},\left(1 \mathrm{~min}^{-\mathrm{a}} \mathrm{m}^{-\boldsymbol{l}}\right)$ & $a$ & $t_{\mathrm{m}} / l_{\mathrm{m}}$ & $t_{1} / l_{1}$ \\
\hline \multirow[t]{2}{*}{20} & 40 & 5.50 & 11.25 & 6.32 & 0.055 & 0.275 & 0.281 \\
\hline & 60 & 5.50 & 17.25 & 6.25 & 0.067 & 0.275 & 0.288 \\
\hline \multirow[t]{3}{*}{40} & 60 & 11.25 & 17.25 & 6.00 & 0.088 & 0.281 & 0.288 \\
\hline & 80 & 11.25 & 23.50 & 5.89 & 0.100 & 0.281 & 0.294 \\
\hline & 100 & 11.25 & 30.00 & 5.79 & 0.111 & 0.281 & 0.300 \\
\hline \multirow[t]{3}{*}{60} & 100 & 17.25 & 30.00 & 5.53 & 0.129 & 0.288 & 0.300 \\
\hline & 120 & 17.25 & 36.75 & 5.42 & 0.139 & 0.288 & 0.306 \\
\hline & 140 & 17.25 & 43.75 & 5.31 & 0.148 & 0.288 & 0.313 \\
\hline \multirow[t]{3}{*}{80} & 140 & 23.50 & 43.75 & 5.07 & 0.163 & 0.294 & 0.313 \\
\hline & 160 & 23.50 & 51.00 & 4.97 & 0.172 & 0.294 & 0.319 \\
\hline & 180 & 23.50 & 58.50 & 4.88 & 0.180 & 0.294 & 0.325 \\
\hline \multirow[t]{3}{*}{100} & 180 & 30.00 & 58.50 & 4.66 & 0.193 & 0.300 & 0.325 \\
\hline & 200 & 30.00 & 66.50 & 4.45 & 0.207 & 0.300 & 0.333 \\
\hline & 220 & 30.00 & 75.50 & 4.21 & 0.231 & 0.300 & 0.343 \\
\hline 120 & 220 & 36.75 & 75.50 & 3.93 & 0.249 & 0.306 & 0.343 \\
\hline
\end{tabular}

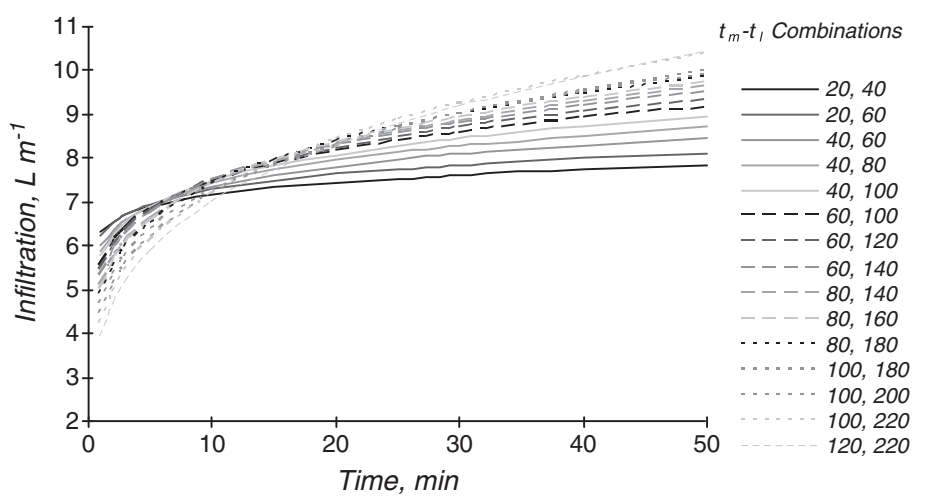

Figure 3. Change in the infiltration equation due to changes in the distance to the first and second measuring points, $1_{\mathrm{m}}$ and $\mathrm{l}_{1}$, respectively.
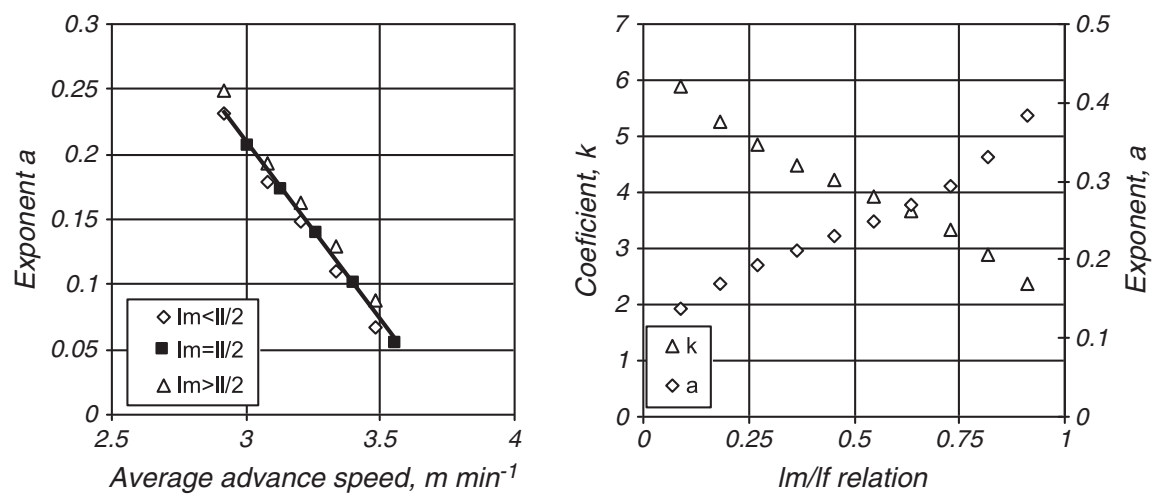

Figure 4. Left: Relation between $a$ and the average advance speed to the second point, $l_{l}$. Right: Influence of the relative position of the first point, $l_{m}$, on the parameters of the Kostiakov infiltration equations, $k$ in $1 \mathrm{~min}^{-\mathrm{a}} \mathrm{m}^{-1}$ and $a$.

calculated from the $V_{1} / V_{\mathrm{m}}$ relation, then it will increase with an increase in $V_{1}$.

The results also indicate that for a given furrow length, the exact position of $l_{\mathrm{m}}$ affects the parameters of the Kostiakov equation, although to a lesser degree (Figure 4, right and Table II). As $l_{\mathrm{m}}$ increases, the value of $a$ also increases, with a corresponding decrease in the value of $k$ which is calculated as a fitting parameter by the two-point method. These results imply that some error in the simulations should be expected for furrows significantly shorter or 
Table II. Effect of the location of the first point, $l_{\mathrm{m}}$, on the parameters of the Kostiakov equation

\begin{tabular}{|c|c|c|c|c|c|c|}
\hline $1_{\mathrm{m}}(\mathrm{m})$ & $l_{1}(m)$ & $1_{\mathrm{m}} / 1_{\mathrm{l}}$ & $t_{m}(\min )$ & $\mathrm{t}_{1}(\min )$ & $\mathrm{k}\left(1 \min ^{-\mathrm{a}} \mathrm{m}^{-1}\right)$ & $\mathrm{a}$ \\
\hline 20 & 220 & 0.091 & 5.50 & 75.5 & 5.88 & 0.138 \\
\hline 40 & 220 & 0.182 & 11.25 & 75.5 & 5.26 & 0.169 \\
\hline 60 & 220 & 0.273 & 17.25 & 75.5 & 4.84 & 0.192 \\
\hline 80 & 220 & 0.364 & 23.50 & 75.5 & 4.50 & 0.212 \\
\hline 100 & 220 & 0.455 & 30.00 & 75.5 & 4.21 & 0.231 \\
\hline 120 & 220 & 0.545 & 36.75 & 75.5 & 3.93 & 0.249 \\
\hline 140 & 220 & 0.636 & 43.75 & 75.5 & 3.66 & 0.269 \\
\hline 160 & 220 & 0.727 & 51.00 & 75.5 & 3.34 & 0.293 \\
\hline 180 & 220 & 0.818 & 58.50 & 75.5 & 2.90 & 0.330 \\
\hline 200 & 220 & 0.909 & 66.50 & 75.5 & 2.36 & 0.383 \\
\hline
\end{tabular}

longer than the control furrows, and that for the proposed irrigation system, $l_{1}$ should be close to the average length of the furrows, and $l_{\mathrm{m}}$ should be near $l_{1} / 2$.

\section{Cablegation hydrogram}

In order to evaluate the precision of the routines used for calculating the cablegation flow rates, the actual flow hydrogram into 15 selected furrows along the $150 \mathrm{~m}$ pipe was measured and compared to the calculated values. The measurements are presented in Figure 5. They indicate that for the initial gates, the calculated flow rates are very close to the observed values $\left(R^{2}=0.99\right)$. For the gates located at the downstream part of the pipe, there is a gradual widening of the range of the flow rates. At these gates, the initial flow rates are higher, and the final flow rates lower than the calculated values. This seems to be caused by a gradual acceleration of water flowing in the pipe, which impacts the pressure head behind the plug.

\section{Evolution of the furrow geometry}

Furrow cross-section geometry has an important influence on hydraulic flow characteristics and surface storage. Since geometry evolves during the irrigation season, it is important to evaluate the influence of this change on the simulations, and assess the need for regular updating of the geometry parameters through the season.

Average field-wide geometries were obtained by averaging furrow geometry from three positions (20, 80 and $140 \mathrm{~m}$ ) along four furrows before the first irrigation and after a series of irrigation events (10 in year 2 and 17 in year 3 ). The latter furrow profiles show a deposition of around $1-2 \mathrm{~cm}$ of sediment at the bottom of the furrow and a small erosion of a few millimetres at the sides (Figure 6). The overall effect is the widening of the furrows, and changes to the parameters of the furrow geometry equation. These changes were greater in year 2 , with a change in the coefficient of the equation from 5.1 to 8.2, although the exponent was little changed. The impacts of this change in geometry on the simulations can be estimated directly using Equation (11), and are presented graphically in Figure 6. The results indicate that for flow rates of up to $11 \mathrm{~s}^{-1}$, the evolution of furrow geometries seems to have very little impact on the speed of flow and thus the distance covered by the advance front in each time increment.

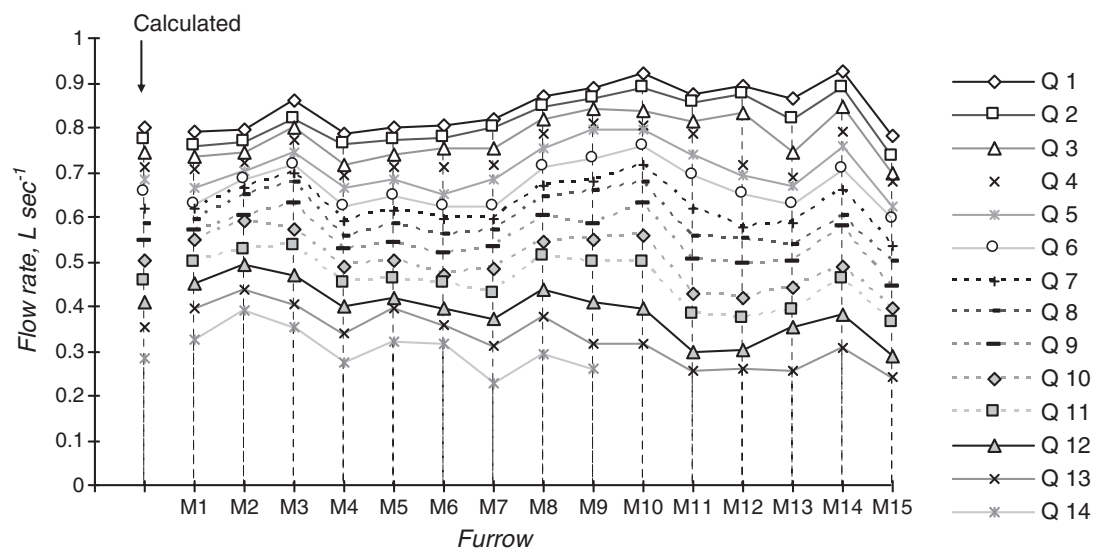

Figure 5. Comparison between simulated and observed hydrograms at 15 furrows located along a $180 \mathrm{~m}$ long pipe, with a $0.02 \mathrm{~m} \mathrm{~m}{ }^{-1}$ slope. 

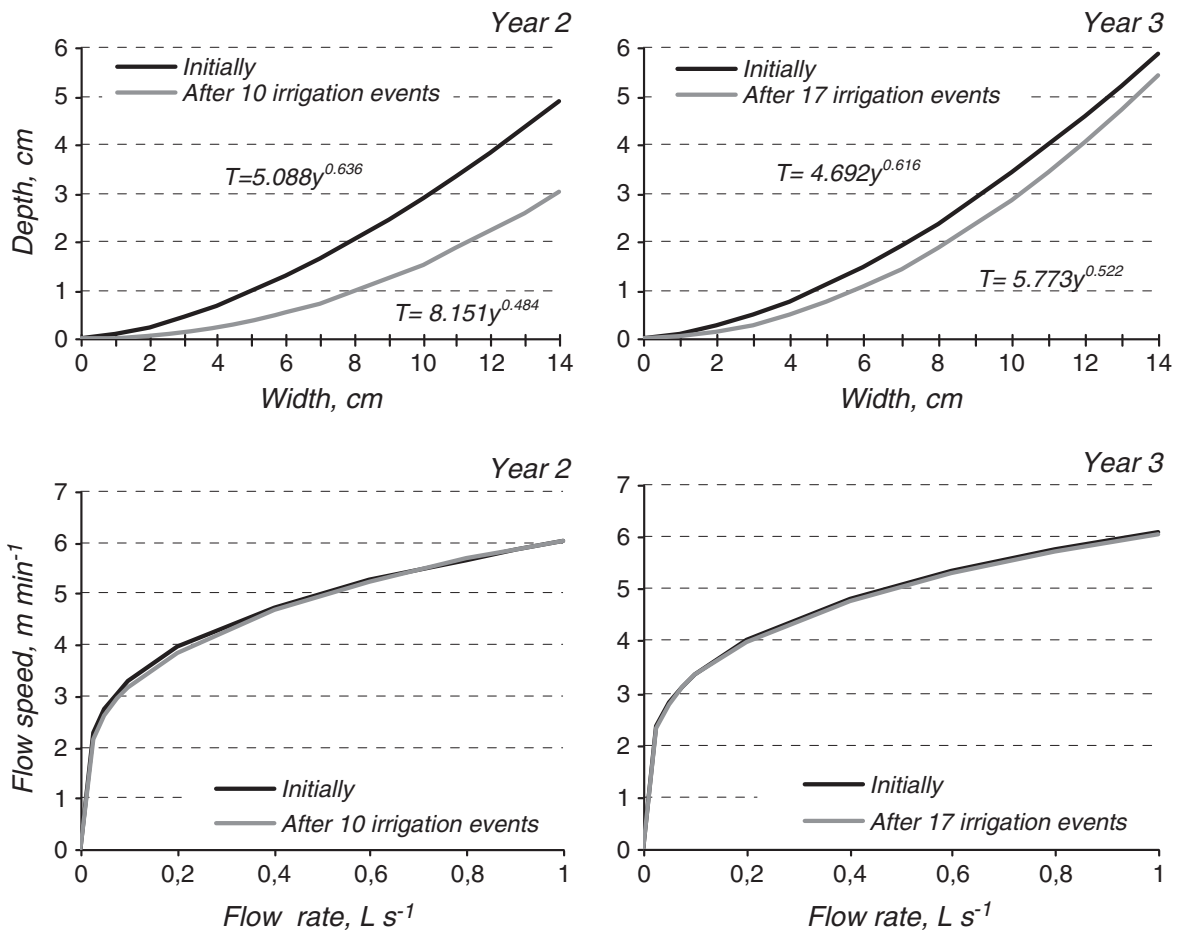

Figure 6. Top: Evolution of furrow geometry after 10 and 17 irrigation events. Bottom: Impact of this change in geometry on flow speed calculated by the Manning's uniform flow equation.

These results indicate that it is not necessary to update the furrow geometry during the irrigation season, as the simulations are not significantly affected by the evolution of the geometry.

\section{Evolution of infiltration through the season}

Data from years 2 and 3 show that the coefficient $k$ decreases rapidly in the first irrigations (Figure 7) and then tends in an asymptote to a value of around $21 \mathrm{~min}^{-\mathrm{a}} \mathrm{m}^{-1}$, clearly portraying the significant decrease in the soil infiltration. On the other hand, the exponent of the equation, $a$, which translates the slope of the infiltration curve, tends to increase slightly through the season, also towards an asymptote.
Despite the difference in infiltration in the three years at the Divor Research Station, data show that after the first initial irrigation events, the parameters of the Kostiakov infiltration equation tend towards similar values (Table III).

Table III. Coefficient and exponent of the Kostiakov infiltration equation after seven/eight irrigations

\begin{tabular}{lcc}
\hline Year & $\mathrm{k} \mathrm{L} \mathrm{min}^{-} \mathrm{a} \mathrm{m}^{-1}$ & $\mathrm{a}$ \\
\hline 1 (irrigation 7) & 2.1 & 0.449 \\
2 (irrigation 7) & 2.62 & 0.289 \\
3 (irrigation 8) & 2.33 & 0.307 \\
\hline
\end{tabular}
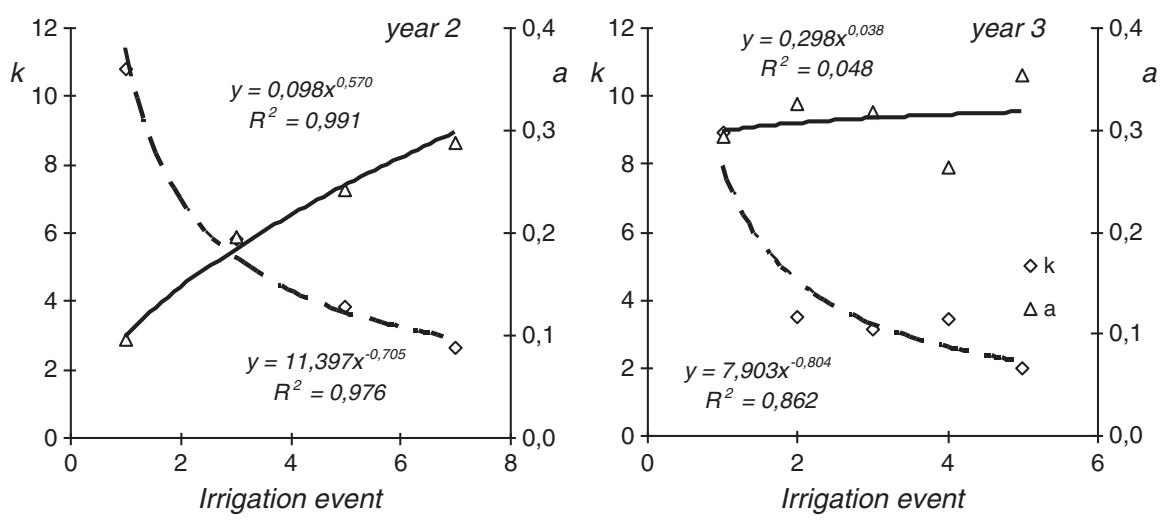

Figure 7. Evolution of the parameters of the Kostiakov infiltration equation with the number of irrigations in year 2 and 3. 

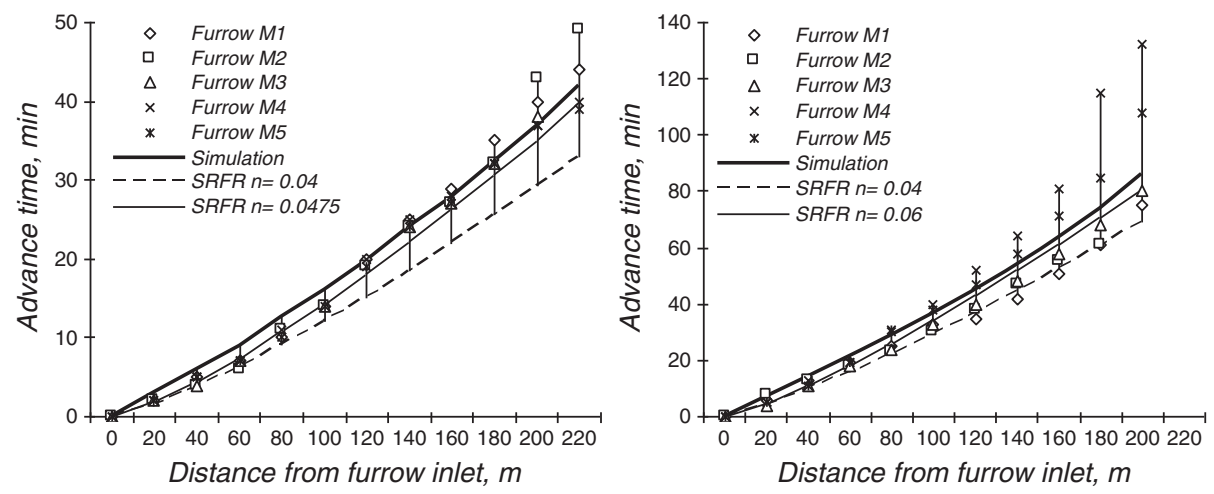

Figure 8. Advance times observed and simulated in irrigation event 2 in year 1 (left) and year 3 (right). Advance times in five furrows with similar length are compared with advance times simulated with the model presented in this work and SRFR using two values of surface roughness.

Table IV. Application efficiency, average application depth and duration of some irrigation events in year 3

\begin{tabular}{|c|c|c|c|c|c|c|}
\hline \multirow[b]{2}{*}{ Irrigation } & \multicolumn{2}{|c|}{ Infiltration equation } & \multirow{2}{*}{$\begin{array}{c}\text { Duration of } \\
\text { irrigation event, (hh:mm) }\end{array}$} & \multirow{2}{*}{$\begin{array}{l}\mathrm{AE} \\
(\%)\end{array}$} & \multirow{2}{*}{$\begin{array}{l}\text { Average application } \\
\text { depth, (mm) }\end{array}$} & \multirow[b]{2}{*}{ Manning's $n$} \\
\hline & $k$ & $a$ & & & & \\
\hline 1 & 8.93 & 0.293 & $32: 22$ & 91.1 & 45.5 & 0.065 \\
\hline 3 & 3.13 & 0.318 & $12: 30$ & 84.4 & 16.4 & 0.055 \\
\hline 8 & 2.37 & 0.307 & $11: 45$ & 87.7 & 16.0 & 0.048 \\
\hline 19 & 1.76 & 0.288 & $12: 28$ & 70.8 & 13.7 & 0.040 \\
\hline 21 & 2.37 & 0.225 & $10: 05$ & 69.1 & 10.8 & 0.045 \\
\hline 27 & 2.22 & 0.256 & $07: 17$ & 74.1 & 8.4 & 0.045 \\
\hline 29 & 2.22 & 0.256 & 08:30 & 70.0 & 9.2 & 0.045 \\
\hline
\end{tabular}

Thus, in all three years, after seven irrigation events, the value of $k$ is around $2.31 \mathrm{~min}^{-\mathrm{a}} \mathrm{m}^{-1}$, and $a$ is around 0.3 . These values can be considered as characteristic of the soil with a smoothed surface, depending more on the soil's intrinsic properties and less on the soil preparation.

\section{The simulations}

The results from observed advance in five furrows of similar length and the simulated advance by the model were compared against advance times calculated using WinSRFR ver. 3.1 (Bautista et al., 2009). For the SRFR simulations the options were no wetted perimeter effect and trapezoidal furrow geometry. The inflow rates were imported from the simulation model developed in this work. The results are presented in Figure 8, and show a wide range of advance times observed at the furrows. It can be seen that the simulation model tends to slightly overestimate advance time at the early part of irrigation. When using SRFR with a standard value of surface roughness (0.04), the SRFR simulations tend to underestimate advance time. When using SRFR with the calibrated surface roughness, then the simulation model and SRFR tend to produce very similar results, although the simulation model estimates slower advance times than SRFR. The results also indicate that the differences between the two simulation models are much smaller than the natural variability of advance between the various furrows of the same field. These results indicate that the simulation model can produce satisfactory advance times in real-time for direct use under field conditions.

The application efficiency, average application depth and duration of some irrigation events are presented in Table IV. It can be seen that the progressive decrease in infiltration with each irrigation resulted in faster advances. The system was able to respond to the decrease in infiltration by decreasing the duration of the irrigation event from $32 \mathrm{~h}$ in the first irrigation to $8: 30 \mathrm{~h}$ in irrigation 29 . The overall application efficiency for the field was very high in the first irrigation events and then decreased gradually through the season. For example in year 3 , the maximum value of $\mathrm{AE}$ was $91.1 \%$ in the first irrigation, and then decreased to around $70 \%$ at the end of the season. This was due to the higher proportion of water leaving the field as runoff due to decreased infiltration.

\section{CONCLUSIONS}

Changes in the position of the two points considered for measuring advance has an important influence on the parameters of the Kostiakov infiltration equation. The 
further the points are from the inlet, the higher will be the value of $a$, and lower the value of $k$. This results in an increase in the infiltration calculated by the two-point method of Elliot and Walker. Thus the infiltration equation should be established in a furrow the length of which is representative of the field to be irrigated. Some variability should be expected between the simulated and observed advance times of furrows that are significantly shorter or longer than the average.

The methodology used for calculating the inflow hydrogram for individual furrows can simulate with precision the hydrogram for the furrows located in the upstream part of the pipe. The momentum of water inside the pipe can cause small changes to the hydrogram at the downstream part of the pipe, although the total water discharged by each gate remains unchanged.

The results indicate that the natural variability in field infiltration, geometry and slopes results in some unavoidable variability of advance times in furrows with the same length. The differences between the simulation model developed here for a small PLC and those carried out using SRFR are much smaller than the natural variability in advance times between furrows of the same field, and thus the model and the simple microcontroller can be used successfully in developing stand-alone automated irrigation systems.

During the first irrigation events, infiltration decreased rapidly, reaching values that are characteristic of the soil. This translated into a gradual and asymptotic decrease in the value of $k$, and a small increase in the value of the exponent $a$. Although the system adjusted the application times to the infiltration rate, it could not avoid a gradual decrease in the application efficiency through the season.

The evolution of furrow geometry through the season did not have an important impact on the speed of flow and the distance covered by the advance front in each time increment. Thus there is no need to update furrow geometry during an irrigation season since the simulations are not significantly affected by the evolution of the geometry.

These results indicate that automation can result in important savings in water and labour and can produce irrigation events with more than $90 \%$ application efficiency. Nevertheless the results also indicate that there are practical limits to what can possibly be achieved with automation and real-time feedback from the field in terms of field-wide efficiency.

\section{REFERENCES}

Alvarez JAR. 2003. Estimation of advance and infiltration equations in furrow irrigation for untested discharges. Agricultural Water Management 60(3): 227-239.

Azevedo CAV, Merkley GP, Walker WR. 1996. Surface irrigation realtime optimization model (SIRTOM). In Proceedings of Computers in Agriculture Conference. ASAE: Cancun Mexico, June 11-14, 1996 872-884.
Barfield BJ, Warner RC, Haan CT. 1981. Applied Hydrology and Sedimentology for Disturbed Areas. Oklahoma Technical Press: Stillwater, OK.

Bautista E, Clemmens AJ, Strelkoff TS, Schlegel J. 2009. Modern analysis of surface irrigation systems with WinSRFR. Agricultural Water Management 96(7): 1146-1154.

Burt CM, Clemmens AJ, Strelkoff TS, Solomon KH, Bliesner RD, Hardy LA, Howell TA, Eisenhauer DE. 1997. Irrigation performance measures: efficiency and uniformity. Journal of Irrigation and Drainage Engineering 123(6): 423-442.

Elliot RL, Walker WR. 1982. Field evaluation of furrow infiltration and advance functions. Transactions of ASAE 25(2): 396-400.

Ettedali HR, Liaghat A, Abbasi F. 2012. Evaluation of the Evalvue model for estimating Manning's roughness in furrow irrigation. Irrigation and Drainage 61(3): 410-415.

Gillies MH, Smith RJ, Williamson B, Shanahan M. 2010. Improving Performance of Bay Irrigation Higher Flow Rates. Australian Irrigation Conference and Exhibition: Sydney; 8-10 June.

Humphries M, Trout TJ. 1990. Feedback control of cablegation systems. In Proceedings of the Third National Irrigation Symposium, ASAE. Phoenix, Ariz; 87-101.

Jayasudha V, Chandrasekaran D. 2001. Fabrication and study of the performance characteristics of a semi-automated cablegation irrigation system. Journal of Agricultural Engineering 38(4): 1-12.

Kemper WD. 1981. Cablegation: I. Cable controlled plugs in perforated supply pipes for automatizing furrow irrigation. Transactions of ASAE 24(6): 1526-1532.

Kemper WD, Kincaid DC. 1982. Cablegation: II. Simulation and Design of the moving-plug gated pipe irrigation system. Transactions of the ASAE 25(2): 388-395.

Kemper WD, Trout TJ, Kincaid DC. 1987. Cablegation automated supply for surface irrigation. In Hillel D (Ed). Advance in Irrigation, Vol. 4. Academic Press, Inc.; 1-66.

Khatri KL, Smith RJ. 2005. Evaluation of methods for determining infiltration parameters from irrigation advance data. Irrigation and Drainage 54(4): $467-482$.

Khatri KL, Smith RJ. 2006. Real-time prediction of soil infiltration characteristics for the management of furrow irrigation. Irrigation Science 25(1): 33-43.

Khatri KL, Smith RJ. 2007. Toward a simple real-time control system for efficient management of furrow irrigation. Irrigation and Drainage 56(4): 463-475.

Kostiakov AN. 1932. On the dynamics of the coefficient of water-percolation in soils and on the necessity for studying it from a dynamic point of view for purposes of ameloriation. Transactions of the 6th Congress of the International Society for Soil Science, Moscow, Part A: 17-21.

Lam Y, Slaughter DC, Wallender WW, Upadhyaya SK. 2007. Machine vision monitoring for control of water advance in furrow irrigation. Transactions of the ASABE 50(2): 371-378.

Moravejalahkami B, Mostafazadeh-Fard B, Heidarpour M, Abbasi F. 2009. Furrow infiltration and roughness prediction for different furrow inflow hydrographs using a zero-inertia model with a multilevel calibration approach. Biosystems Engineering 103: 374-381.

Niblack M, Sanchez CA. 2008. Automation of surface irrigation by cut-off time or cut-off distance. Applied Engineering in Agriculture 24(5).

Oyonarte NA, Mateos L, Palomo MJ. 2002. Infiltration variability in furrow irrigation. Journal of Irrigation and Drainage Engineering 128(1): 36-33.

Sepaskhah AR, Bondar H. 2002. Estimation of Manning roughness coefficient for bare and vegetated furrow irrigation. Biosystems Engineering 82(3): 351-357.

Shahidian S, Serralheiro RP. 2012. Development of an adaptive surface irrigation system. Irrigation Science 30(1): 69-81.

Souza F. 1981. Non-linear Hydrodynamic Model of Furrow Irrigation. PhD thesis presented to the Univeristy of California: Davis, California. 
Strelkoff T, Clemmens AJ. 1981. Dimensionless stream advance in sloping borders. ASCE Journal of Irrigation and Drainage Division 107(4): 361-382.

Trout TJ. 1992. Flow velocity and wetted perimeter effects on furrow infiltration. Transactions of the ASAE 35(3): 855-863.

Trout TJ, Kincaid DC, Kemper WD. 1990. Cablegation: A review of the past decade and prospects for the next. In: Visions of the Future. Proceedings of the Third National Irrigation Symposium, ASAE: 21-27.
Walker WR. 1989. Guidelines for designing and evaluating surface irrigation systems. FAO Irrigation and Drainage Paper 45, Rome, Italy.

Walker WR, Busman J. 1990. Real-time estimation of furrow infiltration. Journal Irrigation and Drainage Engineering 116(3): 299-318.

Walker WR, Skogerboe GV. 1987. Surface Irrigation: Theory and Practice. Prentice-Hall: Englewood Cliffs, New Jersey; p 386. 